\title{
UNSUR-UNSUR PENIPUAN DALAM PASAL 378 KUHP DIKAITKAN DENGAN JUAL BELI TANAH
}

\author{
Oleh : H. Dudung Mulyadi, S.H., M.H. ${ }^{*}$
}

\begin{abstract}
Land has an important role for human life. The need for land by the community is increasingly seen with the advancement of the economy, many people are caught in economic activities such as increased sales and purchase, lease, credit and others. This makes the land has a high economic value. So that society as much as possible to own and control the land to meet the needs of life and survival of the next generation. One of the land ownership rights that can be owned by the community is property rights.

The criminal act of fraud in general (bedrog) is a criminal act that is set in chapter XXV of the Criminal Code stretching between Articles 378-395. That the elements of deception in the sale and purchase of land are contained in Article 378 of the Criminal Code. For anyone who do the sale and purchase with the tricks will be in criminal wear in accordance with the provisions in the Criminal Code. The criminal offenses set forth in chapter XXV of the Criminal Code have many forms, including: basic deception, minor fraud, fraud in buying and selling, fraud removing the boundaries of the pages, etc.From each of these fraudulent forms, having different elements-different.
\end{abstract}

Keywords: Sale and Purchase; Soil

\section{Abstrak}

Tanah memiliki peranan penting bagi kehidupan manusia. Kebutuhan akan tanah oleh masyarakat semakin meningkat dilihat dengan adanya kemajuan ekonomi, banyak masyarakat yang tersangkut dalam kegiatan ekonomi seperti bertambah banyak jual beli, sewa-menyewa, pemberian kredit dan lain-lain. Hal tersebut membuat tanah memiliki nilai ekonomis yang tinggi. Sehingga masyarakat semaksimal mungkin untuk memiliki dan menguasai tanah untuk memenuhi kebutuhan hidup dan kelangsungan hidup generasi berikutnya. Salah satu hak penguasaan atas tanah yang dapat dimiliki oleh masyarakat yaitu hak milik.

Tindak pidana penipuan secara umum (bedrog) adalah tindak-tindak pidana yang di atur dalam bab XXV KUHP yang terentang antara Pasal 378-395. Bahwa unsur-unsur penipuan dalam dengan jual beli tanah terdapat dalam Pasal 378 KUHP. Bagi siapa saja yang melakukan jual beli dengan adanya tipu muslihat maka akan di kenakan pidana sesuai dengan ketentuan dalam KUHP. Tindak pidana yang diatur dalam bab XXV KUHP tersebut, mempunyai banyak sekali bentuk, diantaranya : penipuan pokok, penipuan ringan, penipuan dalam jual beli, penipuan menyingkirkan batas halaman, dan lain-lain. Dari setiap bentuk-bentuk penipuan tersebut, mempunyai unsur-unsur yang berbeda-beda.

Kata Kunci : Jual Beli; Tanah.

\footnotetext{
${ }^{*}$ Dosen Tetap Fakultas Hukum Universitas Galuh
} 


\section{Pendahuluan}

Tanah memiliki peranan penting bagi kehidupan manusia. Kebutuhan akan tanah oleh masyarakat semakin meningkat dilihat dengan adanya kemajuan ekonomi, banyak masyarakat yang tersangkut dalam kegiatan ekonomi seperti bertambah banyak jual beli, sewa-menyewa, pemberian kredit dan lain-lain. Hal tersebut membuat tanah memiliki nilai ekonomis yang tinggi. Sehingga masyarakat semaksimal mungkin untuk memiliki dan menguasai tanah untuk memenuhi kebutuhan hidup dan kelangsungan hidup generasi berikutnya. Salah satu hak penguasaan atas tanah yang dapat dimiliki oleh masyarakat yaitu hak milik.

Dalam Undang-Undang Pokok Agraria, pengertian akan Hak Milik seperti yang dirumuskan di dalam Pasal 20 UUPA yang disebutkan dalam Pasal (1), hak milik adalah hak turun temurun, terkuat dan terpenuhi, yang dapat dipunyai orang atas tanah; (2), hak milik dapat beralih dan dialihkan kepada pihak lain. Hak milik adalah hak yang terkuat dan terpenuhi, di dalam penjelasan Pasal demi Pasal bahwa dalam Pasal 20 Undang-Undang Pokok Agraria disebutkan sifat-sifat daripada hak milik yang membedakannya dengan hak-hak lainnya. (Soedharyo Soimin; 2001;1) Hak Milik itu memberikan wewenang kepada yang punya, yang paling luas jika dibandingkan dengan hak yang lain. Hak Milik dapat dialihkan kepada pihak lain boleh dengan jual-beli, hibah, wasiat, tukar menukar dan lainlain. (Effendi Perangin; 1991 : 238)

Hukum agraria yang terdapat dalam UUPA merupakan hukum pertanahan nasional yang tujuannya adalah :

1. Meletakan dasar-dasar bagi penyusunan hukum agrarian nasional yang akan merupakan alat untuk membawa kemakmuran, kebahagiaan dan keadilan bagi Negara dan rakyat terutama rakyat tani, dalam rangka masyarakat adil makmur.

2. Meletakan dasar-dasar untuk mengadakan kesatuan dan kesederhanaan dalam hukum pertanahan.

3. Meletakan dasar-dasar untuk memberikan kepastian hukum mengenai hakhak atas tanah bagi rakyat seluruhnya.

Salah satu cara mendapatkan tanah sekarang ini adalah melalui jual beli tanah. Dilihat dari pengertian dan eksistensi tanah dan peraturan mengenai tanah begitu tegas, tidak sedikit orang melakukan hal-hal yang bertentangan dengan 
undang-undang berkaitan dengan tanah. Hal tersebut dapat dikatakan sebagai sebuah kejahatan dan dapat dikenakan sanksi berupa pemidanaan apabila memenuhi unsur-unsur yang dimaksud.

Kejahatan sebagai suatu fenomena yang kompleks harus dipahami dari berbagai sisi yang berbeda. Hal ini dibuktikan dalam keseharian, kita dapat menangkap berbagai komentar tentang suatu peristiwa kejahatan yang berbedabeda satu dengan yang lain. Perkembangan teknologi informasi, pengetahuan, bahkan perkembangan hukum, ikut pula berimbas kepada perkembangan kejahatan. Sederhananya, peraturan perundang-undangan yang semakin banyak dan rumit seolah-olah memaksa pelaku kejahatan untuk semakin kreatif dan inovatif dalam melaksanakan kegiatan kejahatannya.

Perkembangan teknologi informasi, pengetahuan, bahkan perkembangan hukum, ikut pula berimbas kepada perkembangan kejahatan. Sederhananya, peraturan perundangundangan yang semakin banyak dan rumit seolah-olah memaksa pelaku kejahatan untuk semakin kreatif dan inovatif dalam melaksanakan kejahatannya. Kejahatan sebagai fenomena sosial yang terjadi dimuka bumi mungkin tidak akan ada habis-habisnya. Tindak pidana di masyarakat dapat terjadi kapan saja dan di mana saja. Jenis tindak pidana itu sendiri beraneka ragam, mulai dari pencurian, pemerkosaan, narkotika, perjudian dan penipuan. Hal ini berdampak pada Perkembangan hukum dalam kehidupan bermasyarakat, semakin menuntut adanya kepastian hukum, baik hubungan hukum individu maupun subyek hukum.

Seiring dengan perkembangan yang ada, tindak pidana penipuan juga mengalami perkembangan yang cukup menyita perhatian. Tindak pidana penipuan yang telah diatur dalam Kitab Undang-Undang Hukum Pidana (KUHP) dengan berbagai modus yang bermacam-macam telah membuat para penegak hukum semakin harus berpikir lebih keras untuk dapat membuktikannya. Banyak hal yang menjadi faktor dari kejahatan penipuan tersebut misalnya faktor kemiskinan, lingkungan, dan adanya kesempatan ataupun keinginan untuk memperoleh uang tanpa harus bekerja keras.

Kejahatan yang semakin meningkat dan sering tersebut merupakan hal yang sangat diperhatikan, sehingga mengundang pemerintah (negara) sebagai pelayan, pelindung masyarakat untuk menanggulangi meluasnya dan bertambahnya kejahatan yang melanggar nilai-nilai maupun norma-norma yang 
hidup dan berlaku di dalam suatu masyarakat sehingga kejahatan tersebut oleh negara dijadikan sebagai perbuatan pidana untuk tindak pidana. Hukum pidana merupakan sarana yang penting dalam penanggulangan kejahatan atau mungkin sebagai obat dalam memberantas kejahatan yang meresahkan dan merugikan masyarakat pada umumnya dan korban pada khususnya. Penanggulangan kejahatan tersebut dapat dilakukan secara preventif (pencegahan) dan refresif (penindakan). Sehubungan dengan itu, tulisan ini akan menganalisis lebih jauh terkait dengan unsur-unsur penipuan dalam Pasal 378 KUHP dikaitkan dengan jual beli tanah.

Sebagai contoh ada kasus jual beli tanah yang ada di Kabupaten Ciamis salah satunya yakni terdapat kasus jual beli tanah dimana penjual menyatakan kepada pembeli bahwa tanah tersebut telah bersertifikat padahal belum bersertifikat dan tanah tersebut telah dijual pada A dan di jual kembali pada B.

\section{Penipuan}

\subsection{Penipuan Menurut Bahasa}

Menurut Kamus Besar Bahasa Indonesia disebutkan bahwa tipu berarti kecoh, daya cara, perbuatan atau perkataan yang tidak jujur (bohong, palsu, dsb), dengan maksud untuk menyesatkan, mengakali, atau mencari untung. Penipuan berarti proses, perbuatan, cara menipu, perkara menipu (mengecoh). (Ananda, S. 2009; 364.) Dengan demikian maka berarti bahwa yang terlibat dalam penipuan adalah dua pihak yaitu orang menipu disebut dengan penipu dan orang yang tertipu. Jadi penipuan dapat diartikan sebagai suatu perbuatan atau membuat, perkataan seseorang yang tidak jujur atau bohong dengan maksud untuk menyesatkan atau mengakali orang lain untuk kepentingan dirinya atau kelompok.

Penipuan berasal dari kata tipu yang artinya menurut kamus besar bahasa Indonesia adalah perbuatan atau perkataan yang tidak jujur (bohong, palsu, dsb) dengan maksud untuk menyesatkan, mengakali, atau mencari untung. Penipuan itu sendiri berarti proses, cara, perbuatan menipu. Kejahatan penipuan itu termasuk materiel delict yang artinya untuk kesempurnaannya harus terjadi akibatnya. Unsur-unsur penipuan yaitu perbuatan yang dilakukan untuk mendapatkan barang atau uang milik orang lain dan keuntungan dengan cara yang buruk. Karena menggunakan identitas palsu seperti nama palsu dan 
kedudukan palsu, dengan rangkaian kebohongan, atau menggunakan tipu muslihat. Dalam penipuan harus ada kausalitas antara tipu muslihat dengan pemberian barang tertentu yang jika tidak adanya tipu muslihat tersebut, maka tidak akan ada pemberian barang tersebut.

\subsection{Penipuan Menurut Pengertian Yuridis}

Tindak pidana penipuan merupakan kejahatan terhadap harta benda yang diatur dalam Buku II KUHP dalam Bab XXV dari Pasal 378 sampai dengan Pasal 395. Kejahatan penipuan di dalam bentuknya yang pokok diatur di dalam Pasal 378 KUHP yang dirumuskan sebagai berikut: "Barang siapa dengan maksud menguntungkan diri sendiri atau orang lain secara melawan hukum dengan memakai nama palsu atau martabat palsu; dengan tipu muslihat, ataupun rangkaian kebohongan, menggerakkan orang lain untuk menyerahkan barang sesuatu kepadanya, atau supaya memberi utang maupun menghapuskan piutang, diancam, karena penipuan, dengan pidana penjara paling lama empat tahun".

Sebagai cara penipuan dalam Pasal 378 KUHP, menurut M. Sudrajat Bassar menyebutkan :

1. Menggunakan nama palsu

2. Menggunakan kedudukan palsu

3. Menggunakan tipu muslihat

4. Menggunakan susunan belit dusta.

Barang siapa dengan maksud untuk menguntungkan diri sendiri atau orang lain secara melawan hukum dengan memakai nama palsu atau martabat (hoedanigheid) palsu, dengan tipu muslihat ataupun rangkaian kebohongan, menggerakan orang lain untuk menyerahkan barang sesuatu kepadanya, atau supaya memberi utang maupun menghapuskan piutang, diancam karena penipuan, dengan pidana penjara paling lama empat tahun.

Pengertian Tindak Pidana Penipuan dengan melihat dari segi hukum sampai sekarang belum ada, kecuali apa yang dirumuskan dalam KUHP. Rumusan penipuan dalam KUHP bukanlah suatu definisi melainkan hanyalah untuk menetapkan unsur-unsur suatu perbuatan sehingga dapat dikatakan sebagai penipuan dan pelakunya dapat dipidana. 
Penipuan menurut Pasal 378 KUHP oleh Moeljatno (2007: 133) sebagai berikut : "Barang siapa dengan maksud hendak menguntungkan diri sendiri atau orang lain secara melawan hukum dengan memakai nama palsu atau martabat (hoedanigheid) palsu; dengan tipu muslihat, ataupun rangkaian kebohongan, menggerakkan orang lain untuk menyerahkan barang sesuatu kepadanya, atau supaya memberi utang maupun menghapuskan piutang, diancam, karena penipuan, dengan pidana penjara paling lama empat tahun."

Berdasarkan unsur-unsur tindak pidana penipuan yang terkandung dalam rumusan Pasal 378 KUHP di atas. Maka R. Sugandhi (1980 : 396-397) mengemukakan pengertian penipuan bahwa: "Penipuan adalah tindakan seseorang dengan tipu muslihat, rangkaian kebohongan, nama palsu dan keadaan palsu dengan maksud menguntungkan diri sendiri dengan tiada hak. Rangkaian kebohongan ialah susunan kalimat-kalimat bohong yang tersusun demikian rupa yang merupakan cerita sesuatu yang seakan-akan benar".

Pengertian penipuan sesuai pendapat tersebut di atas tampak jelas bahwa yang dimaksud dengan penipuan adalah tipu muslihat atau serangkaian perkataan bohong sehingga seseorang merasa terpedaya karena omongan yang seakan-akan benar. Biasanya seseorang yang melakukan penipuan, adalah menerangkan sesuatu yang seolah-olah betul atau terjadi, tetapi sesungguhnya perkataannya itu adalah tidak sesuai dengan kenyataannya, karena tujuannya hanya untuk meyakinkan orang yang menjadi sasaran agar diakui keinginannya, sedangkan menggunakan nama palsu supaya yang bersangkutan tidak diketahui identitasnya, begitu pula dengan menggunakan kedudukan palsu agar orang yakin akan perkataannya. Penipuan sendiri dikalangan masyarakat merupakan perbuatan yang sangat tercela namun jarang dari pelaku tindak kejahatan tersebut tidak dilaporkan kepihak kepolisian. Penipuan yang bersifat kecil-kecilan dimana korban tidak melaporkannya membuat pelaku penipuan terus mengembangkan aksinya yang pada akhirnya pelaku penipuan tersebut menjadi pelaku penipuan yang berskala besar.

\subsection{Unsur-Unsur Penipuan Di dalam KUHP}

Tentang penipuan terdapat dalam Buku II Bab XXV. Keseluruhan Pasal pada Bab XXV ini dikenal dengan nama bedrog atau perbuatan curang. Bentuk pokok dari bedrog atau perbuatan curang adalah Pasal 378 KUHP tentang 
penipuan. Berdasarkan rumusan tersebut di atas, maka Tindak Pdana Penipuan memiliki unsur pokok, yakni :

\section{A. Unsur-unsur Objektif :}

1) Dengan maksud untuk menguntungkan diri sendiri atau orang lain secara melawan hukum. Secara sederhana penjelasan dari unsur ini yaitu tujuan terdekat dari pelaku artinya pelaku hendak mendapatkan keuntungan. Keuntungan itu adalah tujuan utama pelaku dengan jalan melawan hukum, jika pelaku masih membutuhkan tindakan lain, maka maksud belum dapat terpenuhi. Dengan demikian maksud ditujukan untuk menguntungkan dan melawan hukum, sehingga pelaku harus mengetahui bahwa keuntungan yang menjadi tujuannya itu harus bersifat melawan hukum.

2) Dengan menggunakan salah satu atau lebih alat penggerak penipuan (nama palsu, martabat palsu/ keadaan palsu, tipu muslihat dan rangkaian kebohongan). Maksudnya adalah sifat penipuan sebagai tindak pidana ditentukan oleh cara-cara dengan mana pelaku menggerakkan orang lain untuk menyerahkan barang (R. Soenarto Soerodibroto, 1992 : 241).

Adapun alat-alat penggerak yang dipergunakan untuk menggerakkan orang lain adalah sebagai berikut :

a. Nama Palsu, dalam hal ini adalah nama yang berlainan dengan nama yang sebenarnya meskipun perbedaan itu nampaknya kecil. Lain halnya jika si penipu menggunakan nama orang lain yang sama dengan namanya dengan ia sendiri, maka ia dapat dipersalahkan melakukan tipu muslihat atau susunan belit dusta.

b. Tipu Muslihat, yang dimaksud dengan tipu muslihat adalah perbuatanperbuatan yang dilakukan sedemikian rupa, sehingga perbuatan itu menimbulkan kepercayaan atau keyakinan atas kebenaran dari sesuatu kepada orang lain. Jika tipu muslihat ini bukanlah ucapan melainkan perbuatan atau tindakan.

c. Martabat / keadaan Palsu, pemakaian martabat atau keadaan palsu adalah bilamana seseorang memberikan pernyataan bahwa ia berada dalam suatu keadaan tertentu, yang mana keadaan itu memberikan hak-hak kepada orang yang ada dalam keadaan itu.

d. Rangkaian Kebohongan, beberapa kata bohong saja dianggap tidak cukup sebagai alat penggerak. Hal ini dipertegas oleh Hoge Raad 
dalam arrestnya 8 Maret 1926 (Soenarto Soerodibrooto, 1992 : 245), bahwa : "Terdapat suatu rangkaian kebohongan jika antara berbagai kebohongan itu terdapat suatu hubungan yang sedemikian rupa dan kebohongan yang satu melengkapi kebohongan yang lain sehingga mereka secara timbal balik menimbulkan suatu gambaran palsu seolah-olah merupakan suatu kebenaran". Jadi rangkaian kebohongan Itu harus diucapkan secara tersusun, sehingga merupakan suatu cerita yang dapat diterima secara logis dan benar. Dengan demikian kata yang satu memperkuat / membenarkan kata orang lain.

3) Menggerakkan orang lain untuk menyerahkan sesuatu barang, atau memberi utang, atau menghapus utang. Dalam perbuatan menggerakkan orang lain untuk menyerahkan barang diisyaratkan adanya hubungan kausal antara alat penggerak dan penyerahan barang. Hal ini dipertegas oleh Hoge Raad dalam arrestnya Tanggal 25 Agustus 1923 (Soenarto Soerodibroto, 1992 : 242) bahwa : "Harus terdapat suatu hubungan sebab musabab antara upaya yang digunakan dengan penyerahan yang dimaksud dari itu.

Penyerahan suatu barang yang terjadi sebagai akibat penggunaan alatalat penggerak dipandang belum cukup terbukti tanpa menguraikan pengaruh yang ditimbulkan karena dipergunakannya alat-alat tersebut menciptakan suatu situasi yang tepat untuk menyesatkan seseorang yang normal, sehingga orang tersebut terpedaya karenanya, alat-alat penggerak itu harus menimbulkan dorongan dalam jiwa seseorang sehingga orang tersebut menyerahkan sesuatu barang."

Adapun Unsur-unsur tindak pidana penipuan menurut Moeljatno (2002 : 70) adalah sebagai berikut :

1) Ada seseorang yang dibujuk atau digerakkan untuk menyerahkan suatu barang atau membuat hutang atau menghapus piutang. Barang itu diserahkan oleh yang punya dengan jalan tipu muslihat. Barang yang diserahkan itu tidak selamanya harus kepunyaan sendiri, tetapi juga kepunyaan orang lain.

2) Penipu itu bermaksud untuk menguntungkan dirinya sendiri atau orang lain tanpa hak. Dari maksud itu ternyata bahwa tujuannya adalah untuk merugikan orang yang menyerahkan barang itu. 
3) Yang menjadi korban penipuan itu harus digerakkan untuk menyerahkan barang itu dengan jalan :

a. Penyerahan barang itu harus akibat dari tindakan tipu daya.

b. Sipenipu harus memperdaya sikorban dengan satu akal yang diatur dalam Pasal 378 KUHP. Berdasarkan pendapat yang telah dikemukakan tersebut di atas, maka seseorang baru dapat dikatakan telah melakukan tindak penipuan sebagaimana dimaksud di dalam Pasal 378 KUHP, apabila unsur-unsur yang disebut di dalam Pasal 378 KUHP terpenuhi, maka pelaku tindak pidana penipuan tersebut dapat dijatuhi pidana sesuai perbuatannya.

\section{B. Unsur-Unsur Subjektif :}

a. Dengan maksud untuk menguntungkan diri sendiri atau orang lain. Maksud si pelaku dalam melakukan perbuatan menggerakkan harus ditujukan pada menguntungkan diri sendiri atau orang lain, adalah berupa unsur kesalahan dalam penipuan.

b. Secara melawan hak melawan hukum di sini tidak semata-mata diartikan sekedar dilarang oleh undang-undang atau melawan hukum formil, melainkan harus diartikan yang lebih luas yakni sebagai bertentangan dengan apa yang dikehendaki masyarakat, suatu celaan masyarakat.

Berdasarkan pendapat yang telah dikemukakan tersebut di atas, maka seseorang baru dapat dikatakan telah melakukan tindak penipuan sebagaimana dimaksud di dalam Pasal 378 KUHP, apabila unsur-unsur yang disebut di dalam Pasal 378 KUHP terpenuhi, maka pelaku tindak pidana penipuan tersebut dapat dijatuhi pidana sesuai perbuatannya.

\subsection{Bentuk-Bentuk Penipuan, Unsur, dan Akibat Hukumnya}

Adapun secara lebih detail, bentuk-bentuk penipuan tersebut adalah seperti yang tersaji dalam pembahasan berikut.

\section{Penipuan Pokok}

Menurut Pasal 378 KUHP penipuan adalah barang siapa dengan maksud menguntungkan diri sendiri atau orang lain dengan melawan hukum, baik menggunakan nama palsu atau keadaan palsu, maupun dengan tipu daya, ataupun dengan rangkaian perkataan-perkataan bohong, membujuk 
orang supaya menyerahkan barang atau supaya membuat utang atau menghapus piutang.

Dari pernyataan di atas dapat disimpulkan bahwa dalam penipuan tidak menggunakan paksaan akan tetapi dengan tipu muslihat seseorang untuk mempengaruhi orang lain sehingga orang tersebut bertindak tanpa kesadaran penuh.

Unsur-unsur penipuan pokok tersebut dapat dirumuskan :

a. Unsur-unsur objektif :

1. Perbuatan : menggerakkan atau membujuk;

2. Yang digerakkan : orang

3. Perbuatan tersebut bertujuan agar:

a) Orang lain menyerahkan suatu benda;

b) Orang lain memberi hutang; dan

c) Orang lain menghapuskan piutang.

4. Menggerakkan tersebut dengan memakai:
a) Nama palsu;
b) Tipu muslihat,
c) Martabat palsu; dan
d) Rangkaian kebohongan.

b. Unsur-unsur subjektif :

1. Dengan maksud (met het oogmerk);

2. Untuk menguntungkan diri sendiri atau orang lain;

3. Dengan melawan hukum.

\section{Penipuan Ringan}

Penipuan ringan telah dirumuskan dalam Pasal 379 KUHP yang berbunyi :

"Perbuatan yang dirumuskan dalam Pasal 378 jika benda yang diserahkan itu bukan ternak dan harga dari benda, hutang atau piutang itu tidak lebih dari Rp. 250,00 dikenai sebagai penipuan ringan, dengan pidana penjara paling lama tiga bulan atau pidana denda paling banyak Rp. 900,00". Dalam masyarakat kita binatang ternak dianggap mempunyai nilai yang lebih khusus, sehingga mempunyai nilai sosial yang lebih tinggi dari binatang 
lainnya. Akan tetapi, apabila nilai binatang ternak tersebut kurang dari Rp. 250,00 ,-

Unsur-unsur penipuan ringan adalah :

a. Semua unsur yang merupakan unsure pada Pasal 378 KUHP

b. Unsur-unsur khusus, yaitu:

1. Benda objek bukan ternak;

2. Nilainya tidak lebih dari Rp. 250,00-

Selain penipuan ringan yang terdapat menurut Pasal 379 di atas, juga terdapat pada Pasal 384 dengan dinamakan (bedrog) penipuan ringan tentang perbuatan curang oleh seorang penjual terhadap pembeli adalah dengan rumusan :

Perbuatan yang dirumuskan dalam Pasal 383 dikenai pidana paling lama 3 bulan dan denda paling banyak Rp. 900,00- jika jumlah keuntungan tidak lebih dari Rp. 250.00.

\section{Penipuan dalam Jual Beli.}

Penipuan dalam hal jual beli digolongkan menjadi 2 bentuk, yaitu; penipuan yang dilakukan oleh pembeli yang diatur dalam Pasal 379a dan kejahatan yang dilakukan oleh penjual yang diatur dalam Pasal 383 dan 386 .

A. Penipuan yang dilakukan oleh pembeli.

Menurut Pasal 379a yang berbunyi :

Barang siapa menjadikan sebagai mata pencaharian atau kebiasaan untuk membeli benda-benda, dengan maksud supaya dengan tanpa pembayaran seluruhnya, memastikan kekuasaanya terhadap benda-benda itu, untuk diri sendiri maupun orang lain diancam dengan pidana penjara paling lama 4 tahun.

Dalam bahasa asing kejahatan ini dinamakan flessentrekkerij. Dan baru dimuat dalam KUHP pada tahun 1930. Kejahatan ini biasanya banyak terjadi di kota-kota besar, yaitu orang yang biasanya membeli secara bon barang-barang untuk dirinya sendiri atau orang lain dengan maksud sengaja tidak akan membayar lunas. Model yang dilakukan biasanya dengan mencicil atau kredit. Dengan barang yang sudah diserahkan apabila pembeli tidak membayarnya lunas, sehingga merugikan penjual. Dalam hukum perdata hal ini disebut wanprestasi. Akan tetapi, apabila 
sudah dijadikan mata pencaharian atau kebiasaan seperti maksud semula tidak ingin membayar lunas, maka disebut tindak pidana.

Unsur-unsur kejahatan pembeli menurut Pasal 379a yaitu:

a. Unsur-unsur objektif:

1. Perbuatan membeli;

2. Benda-benda yang dibeli;

3. Dijadikan sebagai mata pencaharian atau kebiasaan.

b. Unsur-unsur Subjektif :

1. Dengan maksud menguasai benda tersebut untuk menguntungkan diri sendiri atau orang lain;

2. Tidak membayar lunas harganya.

Agar pembeli tersebut bisa menjadikan barang-barang tersebut sebagai mata pencaharian maka setidaknya harus terdiri dari dua perbuatan dan tidaklah cukup apabila terdiri dari satu perbuatan saja. Akan tetapi, hal ini tidak mutlak harus terdiri dari beberapa perbuatan.

B. Penipuan yang dilakukan oleh penjual.

Adapun bunyi Pasal 383 adalah :

Diancam dengan pidana penjara paling lama satu tahun empat bulan, seorang penjual yang berbuat curang terhadap pembeli:

1. karena sengaja menyerahkan barang lain daripada yang ditunjuk untuk dibeli;

2. mengenai jenis keadaan atau banyaknya barang yang diserahkan, dengan menggunakan tipu muslihat.

C. Penipuan yang dilakukan oleh penjual kedua.

Hal ini disebutkan dalam Pasal 386 yang merumuskan sebagai berikut :

1. barang siapa menjual, menyerahkan, atau menawarkan barang makanan, minuman atau obat-obatan, yang diketahui bahwa itu dipalsu, dan menyembunyikan hal itu, diancam dengan pidana penjara paling lama empat tahun.

2. bahan makanan, minuman atau obat-obatan itu palsu, jika nilainya atau faidahnya menjadi kurang karena sudah dicampur dengan bahan lain.

Adapun yang ditekankan dalam Pasal ini adalah apabila setelah dicampurnya barang makanan, minuman, atau obat-obatan tersebut 
berkurang nilai atau faidahnya, atau bahkan nilai atau faidah barang tersebut hilang sama sekali, maka kasus ini termasuk dalam kasus pidana dan termasuk pemalsuan barang. Oleh karena itu, tidak menjadi kasus pidana apabila setelah dicampur tidak berkurang atau hilang nilai dan faidahnya, maka tidak melanggar Pasal ini.

\section{Penipuan dalam Karya IImiah dan Lain-Lain}

Tindak pidana membubuhkan nama atau tanda palsu pada karya-karya di bidang sastra, di bidang ilmu pengetahuan dan di bidang seni telah diatur dalam Pasal $380 \mathrm{KUHP}$, yang menyatakan :

1. Diancam dengan pidana penjara paling lama 2 tahun 8 bulan atau denda paling banyak lima ribu rupiah: (1) barang siapa menaruh nama atau tanda secara palsu di atas atau di dalam sebuah kesusastraan, keilmuan, kesenian, atau memalsukan nama atau tanda yang asli dengan maksud untuk menimbulkan kesan bahwa karya tersebut berasal dari orang yang nama atau tandanya ditaruh di atas atau di dalam karya tersebut, (2) barang siapa dengan sengaja menjual, menawarkan, menyerahkan, mempunyai persediaan untuk dijual atau memasukkan ke Indonesia karyakarya sastra, ilmiah, seni atau kerajinan yang di dalam atau di atasnya dibubuhi nama atau tanda palsu, atau yang nama atau tandanya yang asli telah dipalsu seakan-akan itu benar-benar buah hasil orang yang nama atau tandanya telah ditaruh secara palsu tadi.

2. Jika karya tersebut kepunyaan terpidana, hakim dapat menyatakan karya itu disita untuk kepentingan Negara.

Selain itu, juga melanggar ayat (1) Undang-Undang No. 19 Tahun 2002 Tentang Hak Cipta, yang berbunyi : "Dalam Undang-undang ini Ciptaan yang dilindungi adalah Ciptaan dalam bidang ilmu pengetahuan, seni, dan sastra, yang mencakup: buku, Program Komputer, pamflet, perwajahan (lay out) karya tulis yang diterbitkan, dan semua hasil karya tulis lain; ceramah, kuliah, pidato, dan Ciptaan lain yang sejenis dengan itu; alat peraga yang dibuat untuk kepentingan pendidikan dan ilmu pengetahuan; lagu atau musik dengan atau tanpa teks; drama atau drama musikal, tari, koreografi, pewayangan, dan pantomim; seni rupa dalam segala bentuk seperti seni lukis, gambar, seni ukir, seni kaligrafi, seni pahat, seni patung, kolase, dan seni terapan; arsitektur; 
peta; seni batik; fotografi; sinematografi; terjemahan, tafsir, saduran, bunga rampai, database, dan karya lain dari hasil pengalihwujudan".

\section{Penipuan dalam Asuransi}

Penipuan dalam Asuransi dibahas dalam dua Pasal, yaitu Pasal 381 dan 382 KUHP. Yang pertama dalam Pasal 381 KUHP merumuskan sebagai berikut : Barang siapa dengan jalan tipu muslihat menyesatkan penanggung asuransi mengenai keadaan yang berhubungan dengan pertanggungan, sehingga disetujui perjanjian, hal mana tentu tidak akan disetujuinya atau setidak-tidaknya tidak dengan syarat-syarat yang demikian, jika diketahuinya keadaan-keadaan sebenarnya diancam dengan pidana penjara paling lama 1 tahun 4 bulan.

\section{Penipuan Persaingan Curang}

Bentuk penipuan ini diatur dalam Pasal 382, yang menyatakan : Diancam denagan maksimum hukuman penjara satu tahun empat bulan atau denda sebesar Rp 900,- barang siapa dengan maksud menetapkan, memelihara, atau menambah hasil perdagangan atau perusahaannya sendiri atau orang lain, melakukan perbuatan yang bersifat menipu untuk memperdayakan khalayak ramai atau seorang tertentu, jika perbuatan itu dapat menimbulkan kerugian pada lawannya bersaing atau lawan bersaing dari orang lain itu.

\section{Stellionaat}

Tindak pidana stellionaat atau dapat disebut penipuan dalam hal yang berhubungan dengan hak atas tanah dirumuskan dalam Pasal 385 yang rumusannya adalah sebagai berikut :

1. Barang siapa dengan maksud menguntungkan diri sendiri atau orang lain secara melawan hukum, menjual, menukar, atau membebani dengan credietverband suatu hak tanah Indonesia, suatu gedung, bangunan, penanaman atau pembenihan diatas tanah dengan hak tanah atas Indonesia padahal diketahui bahwa yang mempunyai hak di atasnya adalah orang lain.

2. Barang siapa dengan maksud yang sama menjual, menukar, atau membebani dengan kredit verband suatu hak tanah Indonesia yang telah 
dibebani kredit verband, atau suatu gudang bangunan, penanaman atau pembenihan di atas tanah yang juga telah dibebani demikian, tanpa memberitahukan tentang adanya beban itu kepada pihak lain.

3. Barang siapa dengan maksud yang sama menggadaikan kredit verband mengenai suatu hak tanah Indonesia dengan menyembunyikan kepada pihak lain bahwa tanah yang behubungan dengan hak tadi sudah digadaikan.

4. Barang siapa dengan maksud yang sama menggadaikan atau menyewakan tanah dengan hak Indonesia padahal diketahui bahwa orang lain mempunyai atau turut mempunyai hak atas tanah itu.

5. Barang siapa dengan maksud yang sama menjual atau menukarkan tanah dengan hak Indonesia yang telah digadaikan padahal tidak diberitahukan pada pihak lain bahwa tanah itu telah digadaikan.

6. Barang siapa dengan maksud yang sama menjual atau menukarkan tanah dengan hak Indonesia untuk suatu masa, padahal diketahui bahwa tanah itu telah disewakan kepada orang lain untuk masa itu juga.

Dari setiap rumusan mempunyai unsur masing-masing. Unsur-unsur tersebut adalah :

1. Unsur obyektif

a) Perbuatan : menjual, menukarkan membebani dengan kredit verband, menggadaikan, menyewakan,

b) Obyeknya : hak atas tanah Indonesia, gedung, banguan, penanaman atau pembenihan diatas tanah dengan hak Indonesia.

2. Unsur Subjektif

a) Maksud untuk menguntungkan diri sendiri atau orang lain

b) Dengan melawan hukum

c) Yang diketahui bahwa yang mempunyai atau yang turut mempunyai hak diatasnya adalah orang lain.

\section{Penipuan dalam Pemborongan}

Jenis pidana ini biasanya dilakukan oleh seorang pemborong bangunan. Biasanya, pelaku menggunakan modus mengurangi berbagai campuran bahan bangunan dari yang semestinya, menggunakan bahanbahan bekas atau yang berkualitas rendah yang tidak sesuai dengan 
perjanjian. Adapun motif dari penipuan ini adalah untuk mendapatkan keuntungan yang sebesar-besarnya.

Tindak pidana jenis ini diatur dalam Pasal 387 KUHP, yang menyatakan :

(1) Diancam dengan pidana penjara paling lama tujuh tahun, seorang pemborong atau ahli bangunan atau penjual bahan-bahan bangunan, yang pada waktu membuat bangunan atau pada pada waktu menyerahkan bahan-bahan bangunan, melakukan suatu perbuatan curang yang dapat membahayakan keamanan orang atau barang, atau keselamatan Negara dalam keadaaan perang.

(2) Diancam dengan pidana yang sama, barang siapa yang tugasnya mengawasi penyerahan barang-barang itu, sengaja membiarkan perbuatan curang.

Adapun unsur-unsur yang terdapat dalam Pasal 387 KUHP tersebut adalah :

a. Pasal 387 KUHP ayat (1) :

1. Seorang pemborong atau ahli bangunan atau penjual bahan-bahan bangunan,

2. Pada waktu membuat bangunan

3. Pada waktu menyerahkan bahan bangunan

4. Yang dapat berakibat : (a) menimbulkan bahaya bagi keselamatan manusia atau barang, (b) menimbulkan bahaya bagi negara pada waktu perang.

b. Pasal 387 ayat (2) :

1. Seorang yang diberi tugas penyerahan barang.

2. Membiarkan perbuatan curang dilakukan.

3. Dengan sengaja.

\section{Penipuan Terhadap Batas Pekarangan}

Adapun yang dimaksud dengan batas halaman/pekarangan adalah segala sesuatu yang dipakai sebagai batas pekarangan. Batas itu diantaranya bisa berupa tembok, kawat berduri, tanggul, dan sebagainya yang berfungsi membatasi antar pekarangan milik orang lain. 
Bentuk penipuan ini diatur dalam Pasal 389 KUHP, yang menyatakan: Barang siapa dengan maksud untuk menguntungkan diri sendiri atau orang lain secara melawan hukum, menghancurkan, memindahkan, membuang, atau membikin tak dapat dipakainya sesuatu yang digunakan untuk menentukan batas pekarangan, diancam dengan pidana penjara paling lama dua tahun delapan bulan.

\section{Penyiaran Kabar Bohong}

Yang dimaksud penyiaran kabar bohong di sini adalah perbuatan menyiarkan kabar bohong yang dimaksudkan oleh pelakunya untuk mempengaruhi berbagai harga barang di pasaran supaya naik turun.

\section{Penipuan dengan Memberikan Gambaran Tidak Benar Tentang Surat Berharga}

Tindak pidana dilakukan dengan modus tidak memberikan gambaran yang senyatanya yang sengaja dilakukan untuk menarik orang lain agar tertarik untuk ikut serta dalam usaha tersebut.Tindak pidana ini diatur dalam Pasal $391 \mathrm{KUHP}$.

\section{Penipuan dengan Penyusunan Neraca Palsu}

Bentuk pidana ini diatur dalam Pasal 392 KUHP, yang menyatakan: Seorang pengusah, seorang pengurus atau komisaris perseroan terbatas, maskapai andil Indonesia atau koperasi, yang sengaja mengumumkan keadaan atau neraca yang tidak benar, diancam dengan pidana penjara paling lama satu tahun empat bulan.

Demikian pembahasan mengenai bentuk-bentuk penipuan. Akan tetapi, masih ada beberapa bentuk yang tidak dicantumkan, misal: Penipuan terhadap penyerahan barang untuk keperluan militer, penipuan dengan nama perdagangan atau merk orang lain, dll. Karena menurut hemat penulis bentukbentuk penipuan tersebut tidak lagi dipandang dari perspektif KUHP, melainkan dari UU yang lebih khusus mengatur tentang bentuk-bentuk tindak pidana tersebut.

\section{Penutup}

Dari pemaparan yang sedemikian ringkas di atas, maka dapat kami simpulkan bahwa tindak pidana penipuan secara umum (bedrog) adalah tindaktindak pidana yang di atur dalam bab XXV KUHP yang terentang antara Pasal 
378-395.Bahwa unsur-unsur penipuan dalam engan jual beli tanah terdapat dalam Pasal 378 KUHP. Bagi siapa saja yang melakukan jual beli dengan adanya tipu muslihat maka akan di kenakan pidana sesuai dengan Ketentuan dalam KUHP. Tindak pidana yang diatur dalam bab XXV KUHP tersebut, mempunyai banyak sekali bentuk, diantaranya: penipuan pokok, penipuan ringan, penipuan dalam jual beli, penipuan menyingkirkan batas halaman, dll.Dari setiap bentukbentuk penipuan tersebut, mempunyai unsur-unsur yang berbeda-beda.

\section{DAFTAR PUSTAKA}

Chazawi, Adami, 2008, Pelajaran Hukum Pidana Bagian I, PT. Raja Grafindo Persada, Jakarta.

Effendi, Erdianto, 2011, Hukum Pidana Indonesia Suatu Pengantar, Refika Aditama, Bandung.

Harsono, Boedi, 2005, Hukum Agraria Indonesia : Sejarah Pembentukan UndangUndang Pokok Agraria, Isi dan Pelaksanaanya, Djambatan, Jakarta.

Lamintang, P.A.F, 1997, DasarDasar Hukum Pidana Indonesia, PT. Citra Aditya Bakti, Bandung.

Perangin, Effendi, 1991, Hukum Agraria di Indonesia : Suatu Telaah dari sudut pandang praktisi hukum, CV. Rajawali. Jakarta. ,1990, Praktek Jual Beli Tanah, CV. Rajawali, Jakarta.

Prodjodikoro, Wirjono, 2009, AsasAsas Hukum Pidana Di Indonesia, Refika Aditama, Bandung.

Projodikoro, Wirjono. 1997. Hukum Perdata tentang Persetujuan-persetujuan Tertentu. Sumur. Bandung.

Retnoningsih, Ana. 2011. Kamus Besar Bahasa Indonesia. Widya Karya. Semarang.

Soesilo, R. , 1995, Kitab UndangUndang Hukum Pidana (KUHP) Serta Komentarkomentarnya Lengkap Pasal Dei Pasal, Politeia, Bogor.

Kitab Undang-Undang Hukum Perdata (Burgerlijk Wetbook voor Indonesie) diterjemahkan oleh Subekti dan R.Tjitrosubidio.

Undang-Undang Nomor 5 Tahun 1960 Tentang Peraturan Dasar Pokok-Pokok Agraria. 